\title{
Post-Fertilization Development of Seed in French Bean Genotypes: Changes in Seed Quality
}

\author{
Parmeshwar Gopala Devhade, Nation Chamling and Asit Kumar Basu \\ Department of Seed Science and Technology, Faculty of Agriculture, Bidhan Chandra Krishi Viswavidyalaya, Mohanpur, Nadia 741 \\ 252, West Bengal, India
}

\begin{abstract}
An experiment was conducted to evaluate physiological maturity of French bean genotypes at District Seed Farm " $\mathrm{D}$ " Block, Bidhan Chandra Krishi Viswavidyalaya, Kalyani, Nadia, West Bengal during winter season of both $2012-2013$ and 2013-2014. All the five genotypes were grown with sufficient population in three replications following randomized block design (RBD) for the purpose of developmental studies. Developing pods were harvested at different stages, starting from 7 days after anthesis (7 DAA) to 49 DAA with an interval of $7 \mathrm{~d}$, including the field maturity stage, thus leading to study on maximum seven different stages. Harvested pods and seeds were utilized for this development programme through dry seed weight, germination and vigour index. Enhancement in dry matter accumulation in seed continued till 42 DAA for Selection 9 and Victoria in both the years; it was 49 and 42 DAA for Sonali in respective years; it was 49 DAA for Abhay in both the years; and for Deepali, it was 42 DAA along with statistically similar magnitude at 49 DAA. Significant enhancement in germination potential of developing seeds continued till 42 DAA for Selection 9 and Deepali, while it was 49 DAA for the other three genotypes. Enhancement in vigour index continued till 49 DAA for all the genotypes except for Selection 9, for which it continued till 42 DAA and then declined.
\end{abstract}

Key words: French bean, seed development, physiological maturity.

\section{Introduction}

French bean (Phaseolus vulgaris L.) is one of the most important legume vegetables and also is one of the important members of bean group. Among all the beans, it is most extensively grown bean because of its short duration and higher nutritive values. It is a valuable source of protein, vitamins and minerals.

Seed development and maturation study is important, because the seeds should be harvested at appropriate stage to ensure good yield associated with viability, vigour and field performance [1]. At physiological maturity, seed achieves desirable characteristics and has maximum viability and vigour. So, it is necessary to harvest crop at physiological maturity to attain desirable quality seeds. Production of quality seeds and its maintenance till next sowing are very important in commercial cultivation of any

Corresponding author: Asit Kumar Basu, professor, research fields: seed development and storage, physiological and biochemical changes. E-mail: asitkumarbasu@gmail.com. crop. Stage of maturity at harvest is one of the most important factors that can influence the quality of seeds [2]. Optimum stage of harvest of pods and seeds determines its quality as well as storage longevity of seeds to a great extent in tropical regions where temperature and humidity are high [3]. Seed viability and vigour are lost gradually after physiological maturity as natural seed deterioration progresses [4]. Harvest maturity is the earliest moment when the seed moisture has declined to a level that makes the crop harvestable for its dry seeds [5]. For mungbean, this moment is when moisture content is $19 \%$ [6] and in dry beans the moisture content varies from $17 \%$ to $25 \%$ $[7,8]$. Considering all these aspects of limitations, the present programme was undertaken to identify proper stage of physiological maturity during seed development.

\section{Materials and Methods}

Five selected genotypes, viz., Sonali, Selection 9, 
Deepali, Abhay and Victoria, used for study on its pod and seed development pattern, were critically observed from seedling emergence till they attained maturity during winter season of both 2012-2013 and 2013-2014. All the five genotypes were grown with sufficient population (approximately 150) in three replications following randomized block design (RBD) for the purpose of developmental studies. Sufficient numbers of flowers (around 500) for each genotype were tagged on a specific date of anthesis to avoid differential environmental influence. Developing pods were harvested at different stages of starting from seven days after anthesis (7 DAA) to grow up to 49 DAA with an interval of $7 \mathrm{~d}$, including the field maturity stage, thus limiting the study to maximum seven different stages. Sufficient pods for each replication were randomly harvested at each developing stage, though number of pods varied depending on the requirement of study in accordance with the particular stage of development, and seeds were separated carefully from the pod wall. Observations were recorded on average dry weight of developing seeds, seed germination (\%) [9] and vigour index, at both the years for all stages of development. Average seedling length was multiplied by germination (\%) for determination of vigour index [10]. Statistical analysis was done with factorial completely randomized design (FCRD) [11].

\section{Results and Discussion}

Average dry matter accumulation continued till 42 DAA, after which it declined in both the years, but the change in the second year from 42 DAA to 49 DAA could be noticed as statistically non-significant. Reduction in dry weight at later stages of development happened not only due to desiccation, but also due to declining trend in accumulation of food reserves [12]. Erratic situation could be revealed for trend in development of seeds of individual genotypes, which may have been resulted in due to varying responsiveness of individual genotypes towards climatic irregularity prevailed during seed development in the second year. It was significant of the highest magnitude at 42 DAA for Selection 9 and Victoria in both the years, 49 DAA for Abhay in both the years with non-significant change from 42 DAA to 49 DAA in first year, and statistically similar with highest magnitude at both 42 DAA and 49 DAA in both the years for Sonali and Deepali along with non-significant change from 35 DAA also in second year (Table 1). Such varying combination of developmental facets recorded for individual genotypes indicate its uniqueness for expression of this vital character. Maximization in dry weight of seeds is considered as an index of seed maturation [10].

Average germination potential of seeds was observed as maximum for Selection 9, followed by Victoria, Deepali, Sonali and Abhay with non-significant difference between Deepali and Victoria in first year; while in the second year, exchange in position between Deepali and Victoria occurred in significant manner and non-significant difference could be noticed between Abhay and Sonali for this parameter (Table 2). Overall enhancement in germination potential of seeds continued significantly till 49 DAA, when average was made over the genotypes, irrespective of the years of experimentation. While considering the performance of individual genotypes, similar pattern of development was followed by Sonali, Abhay and Victoria. Sharp deviation was noted for other two genotypes, for which enhancement in germination potential continued till 42 DAA and then declined at field maturity (49 DAA), though non-significant decline was noticed for Deepali in both the years. Higher germination potential of seeds at all stages for Selection 9 and Deepali in both the years continued till 42 DAA, and lower magnitudes for other three genotypes may be due to unique expression of genotypic preference to environmental conditions prevailed during seed development and maturation 
Table 1 Average dry weight (g) of seed at different maturity stages.

\begin{tabular}{|c|c|c|c|c|c|c|c|}
\hline \multirow{3}{*}{$\begin{array}{l}\text { Genotypes } \\
\text { (V) }\end{array}$} & \multicolumn{6}{|c|}{ Days after anthesis } & \multirow{3}{*}{$\begin{array}{c}\text { Mean } \\
\text { II }\end{array}$} \\
\hline & $14 \mathrm{DAA}$ & $21 \mathrm{DAA}$ & $28 \mathrm{DAA}$ & $35 \mathrm{DAA}$ & $42 \mathrm{DAA}$ & $49 \mathrm{DAA}$ & \\
\hline & II & II & II & II & II & II & \\
\hline Sonali & 0.00370 .0028 & 0.03760 .0385 & 0.05970 .0907 & 0.14190 .1902 & 0.18410 .2071 & 0.19130 .1925 & 0.10310 .1203 \\
\hline $\begin{array}{l}\text { Selection } \\
9\end{array}$ & 0.00570 .0055 & 0.04500 .0434 & 0.11630 .1199 & 0.29680 .3107 & 0.36180 .4089 & 0.32090 .3850 & 0.19110 .2123 \\
\hline Deepali & 0.00170 .0022 & 0.04850 .0401 & 0.17940 .0985 & 0.19670 .2689 & 0.32310 .2719 & 0.31090 .2814 & 0.17670 .1605 \\
\hline Abhay & 0.00430 .0024 & 0.03550 .0208 & 0.09490 .0544 & 0.16980 .1691 & 0.32340 .2795 & 0.34010 .3325 & 0.16130 .1431 \\
\hline Victoria & 0.00470 .0038 & 0.04370 .0244 & 0.06970 .0764 & 0.11610 .1945 & 0.20760 .2062 & 0.14450 .1339 & 0.09770 .1065 \\
\hline \multirow[t]{3}{*}{ Mean } & 0.00400 .0033 & 0.04210 .0334 & 0.10400 .0880 & 0.18420 .2267 & 0.28000 .2747 & 0.26150 .2651 & \\
\hline & \multicolumn{2}{|c|}{$\mathrm{V}$} & \multicolumn{2}{|c|}{$S$} & \multicolumn{3}{|c|}{$\mathrm{V} \times \mathrm{S}$} \\
\hline & $\mathrm{I}$ & II & $\mathrm{I}$ & II & $\mathrm{I}$ & \multicolumn{2}{|c|}{ II } \\
\hline $\mathrm{SE}(\mathrm{m}) \pm$ & 0.0030 & 0.0033 & 0.0034 & 0.0036 & 0.0075 & \multicolumn{2}{|c|}{0.0082} \\
\hline $\mathrm{CD}(0.05)$ & 0.0086 & 0.0095 & 0.0095 & 0.0104 & 0.0212 & \multicolumn{2}{|c|}{0.0232} \\
\hline
\end{tabular}

I: 2012-2013; II: 2013-2014; 14 DAA-49 DAA = stages of development (S); V $\times$ S = genotype $\times$ stages of development interaction.

Table 2 Germination (\%) of seed at different maturity stages.

\begin{tabular}{|c|c|c|c|c|c|c|c|c|c|c|}
\hline \multirow{3}{*}{$\begin{array}{l}\text { Genotypes } \\
\text { (V) }\end{array}$} & \multicolumn{8}{|c|}{ Days after anthesis } & \multirow{2}{*}{\multicolumn{2}{|c|}{ Mean }} \\
\hline & \multicolumn{2}{|c|}{28 DAA } & \multicolumn{2}{|c|}{35 DAA } & \multicolumn{2}{|c|}{42 DAA } & \multicolumn{2}{|c|}{49 DAA } & & \\
\hline & $\mathrm{I}$ & II & $\mathrm{I}$ & II & $\mathrm{I}$ & II & $\mathrm{I}$ & II & $\mathrm{I}$ & II \\
\hline Sonali & $\begin{array}{l}37.78 \\
(38.22)\end{array}$ & $\begin{array}{l}36.67 \\
(37.57)\end{array}$ & $\begin{array}{l}76.67 \\
(61.46)\end{array}$ & $\begin{array}{l}74.56 \\
(60.05)\end{array}$ & $\begin{array}{l}83.33 \\
(66.29)\end{array}$ & $\begin{array}{l}82.22 \\
(65.46)\end{array}$ & $\begin{array}{l}92.22 \\
(74.35)\end{array}$ & $\begin{array}{l}91.11 \\
(73.24)\end{array}$ & $\begin{array}{c}72.50 \\
(58.69)\end{array}$ & $\begin{array}{l}71.14 \\
(59.08)\end{array}$ \\
\hline Selection 9 & $\begin{array}{l}55.56 \\
(48.48)\end{array}$ & $\begin{array}{l}56.67 \\
(49.12)\end{array}$ & $\begin{array}{l}81.11 \\
(64.61)\end{array}$ & $\begin{array}{l}82.22 \\
(65.46)\end{array}$ & $\begin{array}{l}94.45 \\
(77.10)\end{array}$ & $\begin{array}{l}95.11 \\
(78.24)\end{array}$ & $\begin{array}{l}91.11 \\
(73.16)\end{array}$ & $\begin{array}{l}90.00 \\
(72.05)\end{array}$ & $\begin{array}{c}80.56 \\
(64.20)\end{array}$ & $\begin{array}{l}81.00 \\
(66.22)\end{array}$ \\
\hline Deepali & $\begin{array}{l}40.00 \\
(39.52)\end{array}$ & $\begin{array}{l}41.11 \\
(40.17)\end{array}$ & $\begin{array}{l}80.00 \\
(63.79)\end{array}$ & $\begin{array}{l}82.22 \\
(65.53)\end{array}$ & $\begin{array}{l}92.22 \\
(74.35)\end{array}$ & $\begin{array}{l}93.33 \\
(75.62)\end{array}$ & $\begin{array}{l}90.00 \\
(72.05)\end{array}$ & $\begin{array}{l}92.22 \\
(74.43)\end{array}$ & $\begin{array}{c}75.56 \\
(60.70)\end{array}$ & $\begin{array}{l}77.22 \\
(63.94)\end{array}$ \\
\hline Abhay & $\begin{array}{l}38.89 \\
(38.47)\end{array}$ & $\begin{array}{l}37.78 \\
(38.22)\end{array}$ & $\begin{array}{l}71.11 \\
(57.80)\end{array}$ & $\begin{array}{l}70.00 \\
(57.10)\end{array}$ & $\begin{array}{l}82.22 \\
(65.44)\end{array}$ & $\begin{array}{l}81.11 \\
(64.63)\end{array}$ & $\begin{array}{l}94.44 \\
(77.01)\end{array}$ & $\begin{array}{l}93.33 \\
(75.62)\end{array}$ & $\begin{array}{c}71.67 \\
(58.16)\end{array}$ & $\begin{array}{l}70.56 \\
(58.89)\end{array}$ \\
\hline Victoria & $\begin{array}{l}44.45 \\
(42.10)\end{array}$ & $\begin{array}{l}42.22 \\
(40.81)\end{array}$ & $\begin{array}{l}77.78 \\
(62.52)\end{array}$ & $\begin{array}{l}75.45 \\
(60.64)\end{array}$ & $\begin{array}{l}90.00 \\
(72.04)\end{array}$ & $\begin{array}{l}89.22 \\
(71.33)\end{array}$ & $\begin{array}{l}93.33 \\
(75.62)\end{array}$ & $\begin{array}{l}91.11 \\
(73.24)\end{array}$ & $\begin{array}{c}76.39 \\
(61.27)\end{array}$ & $\begin{array}{l}74.50 \\
(61.50)\end{array}$ \\
\hline \multirow[t]{3}{*}{ Mean } & $\begin{array}{l}43.33 \\
(41.46)\end{array}$ & $\begin{array}{l}42.89 \\
(41.18)\end{array}$ & $\begin{array}{l}77.33 \\
(61.91)\end{array}$ & $\begin{array}{l}76.89 \\
(61.76)\end{array}$ & $\begin{array}{l}88.44 \\
(70.58)\end{array}$ & $\begin{array}{l}88.20 \\
(71.05)\end{array}$ & $\begin{array}{l}92.22 \\
(74.35)\end{array}$ & $\begin{array}{l}91.55 \\
(73.71)\end{array}$ & & \\
\hline & \multicolumn{4}{|c|}{$\mathrm{V}$} & \multicolumn{3}{|c|}{$\mathrm{S}$} & \multicolumn{3}{|c|}{$\mathrm{V} \times \mathrm{S}$} \\
\hline & $\mathrm{I}$ & & II & & $\mathrm{I}$ & & & $\mathrm{I}$ & & II \\
\hline$\pm \mathrm{SE}(\mathrm{m})$ & 0.500 & & 0.520 & & 0.447 & & & 1.000 & & 1.041 \\
\hline CD (0.05) & 1.429 & & 1.487 & & 1.278 & & & 2.858 & & 2.975 \\
\hline
\end{tabular}

Figures in parentheses are arc-sine transformed values.

I: 2012-2013; II: 2013-2014; 28 DAA-49 DAA = stages of development (S); V $\times$ S = genotype $\times$ stages of development interaction.

over the years, and/or may be due to non-significant difference in its performance. Reduced magnitude at 49 DAA for Selection 9 and Deepali may have been resulted from over maturity or non-significant expression of the same.

Vigour index has been considered here as joint function of germination (\%) and seedling length. It was determined with the highest magnitude till 42
DAA for Selection 9 in both the years, when average was made over the stages of development, followed by Deepali, Victoria, Abhay and Sonali in first year; while position was inter-changed between Abhay and Victoria in the second year, indicating that Selection 9 possesses the genetic potentiality for production of seeds with high vigour status and reverse scenario for Sonali (Table 3). Seeds produced at 28 DAA were of 
Table 3 Vigour index at different maturity stages.

\begin{tabular}{|c|c|c|c|c|c|c|c|c|}
\hline \multirow{3}{*}{$\begin{array}{l}\text { Genotypes } \\
\text { (V) }\end{array}$} & \multicolumn{7}{|c|}{ Days after anthesis } & \multirow{3}{*}{$\begin{array}{c}\text { Mean } \\
\text { II } \\
\end{array}$} \\
\hline & \multicolumn{2}{|c|}{$28 \mathrm{DAA}$} & $35 \mathrm{DAA}$ & \multicolumn{2}{|c|}{$42 \mathrm{DAA}$} & \multicolumn{2}{|c|}{49 DAA } & \\
\hline & $\mathrm{I}$ & II & II & I & II & I & II & \\
\hline Sonali & 965.02 & 894.99 & $2,549.792,383.89$ & $3,306.74$ & $3,181.59$ & $4,103.80$ & $3,949.23$ & $2,731.342,602.43$ \\
\hline Selection 9 & $1,594.25$ & $1,686.50$ & 2,997.13 3,171.16 & $4,431.83$ & $4,611.13$ & $4,394.60$ & $4,429.20$ & $3,354.453,474.50$ \\
\hline Deepali & $1,175.07$ & $1,236.69$ & 2,827.20 3,030.15 & $4,073.20$ & 4,199.38 & $4,695.30$ & $4,934.31$ & 3,192.69 3,350.13 \\
\hline Abhay & $1,176.59$ & $1,061.85$ & $2,659.092,475.67$ & $3,735.84$ & $3,593.27$ & $4,843.49$ & $4,631.46$ & $3,103.752,940.56$ \\
\hline Victoria & $1,355.77$ & $1,228.40$ & 2,934.45 2,727.18 & $3,868.80$ & $3,705.60$ & $4,506.85$ & $4,260.65$ & $3,166.472,980.46$ \\
\hline \multirow[t]{3}{*}{ Mean } & $1,253.34$ & $1,221.69$ & 2,793.53 2,757.61 & $3,883.28$ & 3,858.19 & $4,508.81$ & $4,440.97$ & \\
\hline & \multicolumn{2}{|r|}{$\mathrm{V}$} & \multicolumn{3}{|c|}{$S$} & \multicolumn{3}{|c|}{$\mathrm{V} \times \mathrm{S}$} \\
\hline & I & II & I & II & & $\mathrm{I}$ & & II \\
\hline$\pm \mathrm{SE}(\mathrm{m})$ & 20.301 & 22.357 & 18.158 & 19. & 997 & 40.602 & & 44.714 \\
\hline CD (0.05) & 58.026 & 63.903 & 51.900 & & 156 & 116.052 & & 127.806 \\
\hline
\end{tabular}

I: 2012-2013, II: 2013-2014; 28 DAA-9 DAA = stages of development (S); V $\times$ S = genotype $\times$ stages of development interaction.

the lowest vigour status in both the years, after which consistent enhancement with decreasing trend could be noticed up to 49 DAA, when average was made over the genotypes. Exactly similar pattern of enhancement could be noticed for individual genotypes with the advancement in development. Selection 9 was identified as one exception, for which enhancement in vigour index continued till $42 \mathrm{DAA}$ and then reduced in non-significant manner at 49 DAA in first year, though significant reduction could be noticed during the second year; pre-dominant role of environmental fluctuation may be responsible for such variation. Concomitant consideration of vigour index, germination (\%) and dry weight of developing seeds of individual genotypes clearly indicate the attainment of stage of physiological maturity: 49 DAA for both Sonali and Abhay, 42 DAA for Selection 9 only, maybe 42 DAA for Deepali and 49 DAA for Victoria, considering the status of major component parameters. Similar observations were recorded by Basu and Moharana [13] with regard to the trend in changes of seed quality parameters in Lablab bean. They also noticed that variation in physiological maturity of seed is dependent on genetic makeup of the genotypes.

\section{Conclusions}

Genotype specific potential could be noticed for production of seeds with higher vigour status after post-fertilization development. Attainment of physiological maturity mostly depends on genetic architecture of individual genotypes. Harvesting at 49 DAA may be advised for achieving seeds with better quality in general, though it can be made at 42 DAA for the early types.

\section{References}

[1] Dharmalingam, C., and Basu, R. N. 1990. "Seed Development and Maturation Studies in Mungbean.” Seed Res. 18 (1): 1-6.

[2] Demir, I., Ashirov, A. M., and Mavi, K. 2008. "Effect of Seed Production Environment and Time of Harvest on Tomato (Lycopersicon esculentum) Seedling Growth.” Res. J. Seed. Sci. 1 (1): 1-10.

[3] Lassim, M. B. M., and Chinn, H. F. 1987. "Some Trends in Development and Maturation in Cowpea." Acta Hort. 215: 25-30.

[4] Dornbos, D. L. 1995. "Production Environment and Seed Quality.” In Seed Quality: Basic Mechanisms and Implications, edited by Basra, A. S. London: Food Products Press, 119-45.

[5] Tekrony, D. M., and Egli, D. B. 1997. “Accumulation of Seed Vigour during Development and Maturation.” In Basic and Applied Aspects of Seed Biology, edited by Ellis, R. H., Black, M., Murdoch, A. J., and Hong, T. D. Dordrecht: Kluwer Academic Publishers, 369-84.

[6] Dharmalingam, C., and Basu, R. N. 1998. "Seed Quality in Relation to Position of Seed in Pod at Different Maturity Periods in Mungbean Cultivar CO-3.” Seed Res. 16 (2): 168-72.

[7] Van Venter, H. A., Demir, I., Meillon, S., and Loubser, W. A. 1996. "Seed Development and Maturation in 
Edible Dry Bean (Phaseolus vulgaris L.) cv. Teebus.” South African J. of Plant and Soil 13 (2): 47-50.

[8] Kelly, A. F. 1988. Seed Production of Agricultural Crops. Essex, England: Longman Scientific \& Technical Publisher.

[9] International Seed Testing Association (ISTA). 1985. "International Rules for Seed Testing." Seed Science and Technology 13: 229-355.

[10] Abdul-Baki, A. A., and Anderson, J. D. 1973. "Vigour Determination in Soybean by Multiple Criteria.” Crop Sci. 13 (6): 630-3.
[11] Gomez, K. A., and Gomez, A. A. 1983. Statistical Procedures for Agriculture Research. New York: John Willing and Sons, Inc..

[12] Jerlin, R., Shrimathi, P., and Vanangamudi, K. 2001. “Seed Physiological Maturity and Maturity Indices.” In Recent Techniques and Participating Approaches on Quality Seed Production. Coimbatore, India: Department of Seed Science and Technology, TNAU, 123-6.

[13] Basu, A. K., and Moharana, R. L. 2012. "Variation in Seed Development Pattern in Lablab Bean Cultivars.” Acta Hort. 958: 121-6. 